\title{
Effect of Endophytic Bacteria on Tomato Plant Growth Promotion and Tomato Early Blight Management
}

\author{
B. Sai Sushma*, B. Vidya Sagar, S. Triveni and G. Uma Devi \\ Department of Plant Pathology, Professor Jayashankar Telangana State Agricultural \\ University (PJTSAU), Rajendranagar, Hyderabad, India \\ *Corresponding author
}

\section{A B S T R A C T}

\begin{tabular}{|l|} 
Ke y w o r d s \\
Endophytic \\
Bacteria, Tomato \\
early blight
\end{tabular}

\section{Introduction}

Tomato (Lycopersicon esculentum Mill.) is one of the most important vegetable crops in India. It is a good source of vitamins, minerals, organic acids, essential amino acids and dietary fibers. The productivity of tomato is low due to several abiotic and biotic stresses. Among the biotic factors associated with low yield, diseases occupy a predominant position. Tomato is attacked by many diseases as early blight (Alternaria solani), damping off (Pythium ultimum, Phytophthora), leaf spots (Septoria and Stemphylium), bacterial fruit canker (Clavibacter michiganense subsp. michiganense), spotted wilt (virus), mosaic (virus) and nematodes in its growth stages. Among the fungal diseases, early blight caused by Alternaria solani (Ellis and Martin) Sorauer is the most destructive disease which causes severe damage during all the stages of plant development.

The disease appears in three stages causing collar rot, leaf blight and stem canker and becomes a serious problem during fruiting period in kharif (Datar et al., 1981). The symptoms first appear on older leaves and then progress to younger leaves and on the fruits, the symptoms appear similar to those of leaf symptoms with dark concentric rings. 
The pathogen causes seedling blight in tomato that result in development of dark lesions on rootlets. The calyx and blossom may also get affected by Alternaria solani in susceptible genotypes (Pandey et al., 2003). Fungicides like mancozeb and captan are used to manage Alternaria blight. The most widely used approach for management of the disease is application of fungicides, leads to accumulation of fungicide residues, development of resistance in the pathogen, environmental pollution, and reduction of beneficial microbe population. Hence, the study was carried out to develop an ecofriendly management strategy for early blight disease in tomato by using endophytic bacteria.

Endophytic bacteria can be defined as those bacteria that can be extracted from surface sterilized plant tissue and do not harm the plant. After they gain entry into the plant, they may be either localised at the point of entry or spread through the plant (Hallman et al., 1997). Endophytes enter into plant tissue primarily through the root zone. Aerial portions of the plant may also aid in entry of endophytes (Kobayashi and Palumbo, 2000). Endophytes synthesize bioactive compounds like alkaloids, steroids, terpenoids, peptides, polyketones, flavonoids, quinols and phenols that stimulate plant growth and increase resistance to plant pathogens (Rosenblueth and Romero, 2006). Use of endophytic bacteria can be considered as a new source of biocontrol agents in the plant disease management (Backman et al., 2008), as they share the same ecological niche as that of plant pathogens, which makes them suitable for biocontrol (Ryan et al., 2008).

The present study evaluates the potential endophytes under in vitro and glass house conditions against Alternaria blight of tomato.

\section{Materials and Methods}

\section{Geographical location}

All the experiments were carried out in the glasshouse and laboratory at Department of Plant Pathology, and Department of Microbiology and Bioenergy, College of Agriculture, Professor Jayashankar Telangana State Agricultural University, Rajendranagar, Hyderabad, Telangana state.

\section{Collection of diseased samples}

Tomato leaves and fruits that showed early blight symptoms were collected from tomato fields in Agricultural Research Institute, Professor Jayashankar Telangana State Agricultural University, Hyderabad. The samples were brought in polythene bags to the laboratory for isolation and identification of the pathogen.

\section{Isolation of pathogen}

The isolation of the pathogen from early blight infected tomato leaves was carried out under aseptic conditions by the tissue segment method. Small bits of tomato leaves comprising of both diseased and healthy tissues were cut with a sharp sterilized blade. These bits were surface sterilized by immersing in $1 \%$ Sodium hypochlorite for one minute and then washed with three changes of sterile water and then blot dried on sterile paper towels. Later, they were transferred to Potato Dextrose Agar plates and incubated at $25 \pm 1^{\circ} \mathrm{C}$ for seven days.

\section{Antagonistic activity of endophytic bacteria against Alternaria solani in vitro}

The antifungal activity of all the isolated endophytic bacteria against $A$ solani on PDA was evaluated by following dual-culture technique. Each individual treatment was 
replicated three times and the colony diameter of the pathogen was measured 6 days after incubation at $25 \pm 2{ }^{\circ} \mathrm{C}$. The inhibition rate (Vincent, 1947) of the pathogen was calculated using the formula

$\mathrm{R}=(\mathrm{CD}-\mathrm{TD} / \mathrm{CD}) \mathrm{X} 100$

Where,

$\mathrm{R}=$ per cent inhibition of mycelial growth, $\mathrm{CD}=$ Radial growth of test pathogen in control $(\mathrm{mm}), \mathrm{TD}=$ Radial growth of test pathogen in treatment $(\mathrm{mm})$

Plant growth promotion of tomato by endophytic bacteria

The plant growth-promoting activity of the potential endophytic bacteria was assessed based on seedling vigour index by the standard roll towel method (ISTA, 1993).

The germination percentage, root length and shoot length of the individual seedlings was calculated. The vigour index of the seedlings was calculated using the formula given below (Abdul-Baki et al., 1973).

Vigour index $=$ (mean root length + mean shoot length) $\mathrm{x} \%$ germination.

Evaluation of endophytic bacteria against Alternaria solani under glass house conditions

The tomato variety Arka Vikas was used in the field trial for the evaluation of potential endophytic bacteria against early blight disease. Seed treatment of the endophytic bacterial isolates was done prior to sowing. The seeds were inoculated with a bacterial inoculum of $10^{8} \mathrm{CFU} / \mathrm{ml}$. Soil drench with the bacterial suspension was carried out ten days after transplanting the seedlings. For the soil drench, the surrounding soil was drenched with $100 \mathrm{ml}$ of bacterial inoculum and for foliar spray, the inoculum was sprayed on to the surface of all the leaves after transplanting. The experiment was conducted in factorial design with nine treatments and four replications.

\section{Results and Discussion}

\section{Screening of endophytic bacteria against} Alternaria solani under in vitro conditions

Most of the bacteria were found to inhibit the pathogen by 31 to 63 per cent (Table 1). Among all the isolates, five isolates (EBT3, EBT8, EBT14, EBT18 and EBT22) were highly effective in inhibiting the mycelial growth of the pathogen. Maximum per cent inhibition was recorded by the isolate EBT22 (62.66) per cent while minimum (32.04) inhibition recorded by the isolate EBT24.

The isolate EBT8 and EBT18 showed 60.99 per cent and 53.84 per cent reduction over control. The isolates EBT3 and EBT 14 were on par with each other with per cent inhibition of 51.07 and 52.17 per cent respectively. The bacterial isolate EBT15 inhibited A. solani by 31.33 percent.

Among thirty four bacterial isolates tested for antagonism against phytopathogens, the gram positive isolates showed strong inhibition (Ghai et al., 2007) and similarly in our current study, Bacillus isolates have inhibited the pathogen to a greater extent compared to other isolates.

The isolate EBT18 has also recorded siderophore production which might be the reason for the antagonistic activity of EBT18 against $A$. solani under in vitro (53.84 per cent inhibition) and glass house conditions. Similarly, the endophytic bacteria Bacillus stratosphericus strain LW-O3 isolated from Lilium wardii was found to be antagonistic 
towards four fungal pathogens namely, Botryosphaeria dothidea, Botrytis cinerea and Fusarium fujikuroi and Fusarium oxysporum with an inhibition percentage of $74.56 \pm$ $2.35 \%, 71.91 \pm 2.87 \%, 69.54 \pm 2.73 \%$ and $65.13 \pm 1.91 \%$ respectively (Khan et al., 2020).

\section{Effect of endophytic bacteria on tomato plant growth}

\section{Germination percent}

The results showed that on treatment with endophytic bacteria alone, isolate EBT18 has shown highest germination per cent of 88 per cent (Table 2). The isolates EBT22 and EBT8 were on par with each other with a germination per cent of 74.67 and 74 per cent respectively. The isolate EBT14 recorded 72 per cent germination followed by isolate EBT3 which has shown 70 per cent of germination.

When endophytic bacteria were tested for growth promotion, the Bacillus subtilis strain EPCO16 and EPC5 have recorded a germination per cent of 93.5 and 88.5 per cent respectively (Subramaniam et al., 2012).

The effect of eight endophytic bacteria isolated from weed plants were tested for promotion of growth parameters of tomato and all the bacterial strains increased germination up to 83 per cent but the Bacillus spp. strain PF3 was found to be most promising (Haddad et al., 2013).

When the isolates of endophytic bacteria were combined with the pathogen and applied to the seed, the isolate EBT18 has shown highest germination per cent $(80 \%)$ followed by the isolate EBT14 (71.67 \%). The least germination per cent was recorded by isolates EBT3 and isolate EBT8 with germination of 62 and 64 per cent respectively.

\section{Root length and shoot length}

Of the five isolates tested alone, the isolate EBT18 has shown maximum root length of $18.67 \mathrm{~cm}$ and shoot length of $15.91 \mathrm{~cm}$ respectively. The isolate EBT8 and isolate EBT14 were on par with each other with root lengths of $14.63 \mathrm{~cm}$ and $14.50 \mathrm{~cm}$, shoot lengths of $12.37 \mathrm{~cm}$ and $12.56 \mathrm{~cm}$ respectively. The isolate EBT22 recorded a root length of $12.26 \mathrm{~cm}$ and shoot length of $10.80 \mathrm{~cm}$. However, the isolate EBT3 has recorded minimum root and shoot length of $10.88 \mathrm{~cm}$ and $8.17 \mathrm{~cm}$.

Similar results were obtained when endophytic bacteria were applied, with the highest shoot length of $18.4 \mathrm{~cm}$ by the Bacillus isolate EPC016 and the highest root length of $16.1 \mathrm{~cm}$ by the Bacillus isolate EPC5 (Subramaniam et al., 2012). Inoculation of endophytic bacteria on chilli seedlings resulted in a maximum shoot length of $21.4 \mathrm{~cm}$ by the isolate BETS 14 and a minimum shoot length of 13.5 by the isolate BECS1 (Amaresan et al., 2012).

The isolates of endophytic bacteria when applied in combination with $A$. solani, the highest root length and shoot length were recorded by the isolate EBT22 with a root length of $15.37 \mathrm{~cm}$ and shoot length of 13.05 $\mathrm{cm}$ followed by EBT14 which showed a root length of $13.70 \mathrm{~cm}$ and shoot length of 12.02 $\mathrm{cm}$. The isolate EBT22 when applied along with $A$. solani has shown root and shoot length of $11.01 \mathrm{~cm}$ and $8.88 \mathrm{~cm}$. The isolates EBT8 and EBT3 have shown a root length of $9.20 \mathrm{~cm}$ and $8.23 \mathrm{~cm}$, a shoot length of 8.79 $\mathrm{cm}$ and $6.20 \mathrm{~cm}$ respectively.

\section{Vigour index}

The results revealed that when endophytic bacteria were applied alone to the seed, the isolate EBT18 recorded highest seedling 
vigour index of 3302 followed by the isolate EBT14 that showed vigour index of 2492 (Table 2). A vigour index of 2014.77 was recorded by the isolate EBT8. The isolates EBT3 and EBT22 showed a vigour index of 1352 and 1714.73 respectively.

In the treatment of endophytic bacteria plus $A$. solani, the isolate EBT18 showed highest seedling vigour index of 2402.13 followed by the isolate EBT14 which has shown a vigour index of 1510.60 . The least vigour index was recorded by the isolate EBT3 when combined with A. solani (728.33) which is less than the uninoculated control (1073.55).

The bacterial strain Bacillus cereus EHR1 has shown highest vigour index of 3603 in tomato followed by a vigour index with the respective values of 3247 and 3213 by Pseudomonas spp. PS1 and Bacillus amyloliquefaciens OS4 (Haddad et al., 2013). The endophytic Bacillus isolates that have shown vigour index values of 3225.75 and 2814.30 respectively (Subramaniam et al., 2012)].

It can be inferred (Table 2) that all the isolates when applied alone were found effective in promoting the growth parameters of tomato plant and all the endophytic bacterial isolates except EBT3 and EBT22. The isolate EBT8, isolate EBT14 and isolate EBT18 were effective in inhibiting the growth of pathogen and thereby resulting in enhancement of plant growth.

The superiority of the isolate EBT18 in plant growth might be due to the highest $(+++)$ production of IAA by the isolate that resulted in plant growth promotion in standard roll towel method under in vitro conditions. Similarly, CEFR-3 (Pseudomonas aeruginosa), an endophytic bacteria isolated from chilli fruit for plant growth promotion produced higher amount of IAA and increased the growth of the plant (Allu et al., 2014).

\section{Evaluation of endophytic bacteria against Alternaria solani underglass house conditions}

All the treatments were effective in reducing the disease index of early blight caused by $A$. solani. However, the magnitude of disease reduction varied from treatment to treatment.

Among the treatments, the per cent disease index ranged from 20.30 per cent to 38.82 per cent in comparison with 48.33 per cent in control. The isolate EBT18 recorded minimum PDI of 20.30 per cent when applied as seed treatment + soil drench with a per cent disease reduction of 57.94 when compared to control whereas the highest PDI (38.82) was recorded by the isolate EBT3 when applied as foliar spray with a disease reduction of 19.60 per cent.

Among the five potential isolates of endophytic bacteria, the isolate EBT18 was found to be superior in reducing the per cent disease index of tomato early blight caused by A. solani irrespective of the treatments imposed followed by the isolate EBT14, except in treatments where the endophytic bacteria was applied as seed treatment + foliar spray. When the isolates were applied alone, the seed treatment recorded a PDI ranging from 28.05 to 36.27 per cent with the minimum (28.05) disease index by the isolate EBT18 and maximum (36.27) by the isolate EBT3. The foliar application resulted in a disease index in the range of 26.46 to 38.82 per cent with the minimum disease index by the isolate EBT18 and maximum disease index by the isolate EBT3. Soil drench recorded a per cent disease index ranging from 24.85 to 36.88 with the minimum disease index by the isolate EBT18 and maximum disease index by the isolate EBT3. 
Int.J.Curr.Microbiol.App.Sci (2020) 9(11): 2362-2374

Table.1 Effect of endophytic bacteria on radial growth of Alternaria solani

\begin{tabular}{|c|c|c|c|}
\hline S.No & Isolate & Radial growth of $\boldsymbol{A}$. solani & Percent reduction over control \\
\hline 1 & EBT1 & 69.90 & $0.00(0.00)^{*}$ \\
\hline 2 & EBT2 & 69.90 & $\begin{array}{c}0.00 \\
(0.00)\end{array}$ \\
\hline 3 & EBT3 & 34.20 & $\begin{array}{c}51.07 \\
(45.59)\end{array}$ \\
\hline 4 & EBT4 & 47.40 & $\begin{array}{c}32.18 \\
(34.55)\end{array}$ \\
\hline 5 & EBT5 & 46.60 & $\begin{array}{c}33.33 \\
(35.25)\end{array}$ \\
\hline 6 & EBT6 & 69.90 & $\begin{array}{c}0.00 \\
(0.00)\end{array}$ \\
\hline 7 & EBT7 & 69.90 & $\begin{array}{c}0.00 \\
(\mathbf{0 . 0 0})\end{array}$ \\
\hline 8 & EBT8 & 27.26 & $\begin{array}{c}60.99 \\
(51.33)\end{array}$ \\
\hline 9 & ЕВТ9 & 69.90 & $\begin{array}{c}0.00 \\
(0.00)\end{array}$ \\
\hline 10 & EBT10 & 69.90 & $\begin{array}{c}0.00 \\
(0.00)\end{array}$ \\
\hline 11 & EBT11 & 44.50 & $\begin{array}{c}36.33 \\
(37.05)\end{array}$ \\
\hline 12 & EBT13 & 47.13 & $\begin{array}{c}32.57 \\
(34.78)\end{array}$ \\
\hline 13 & EBT14 & 33.43 & $\begin{array}{c}52.17 \\
(46.23)\end{array}$ \\
\hline 14 & EBT15 & 48.00 & $\begin{array}{c}31.33 \\
(34.02)\end{array}$ \\
\hline 15 & & & 0.00 \\
\hline
\end{tabular}


Int.J.Curr.Microbiol.App.Sci (2020) 9(11): 2362-2374

\begin{tabular}{|c|c|c|c|}
\hline & EBT16 & 69.90 & $(0.00)$ \\
\hline 16 & EBT17 & 46.73 & $\begin{array}{c}33.14 \\
(35.13)\end{array}$ \\
\hline 17 & EBT18 & 32.26 & $\begin{array}{c}53.84 \\
(47.18)\end{array}$ \\
\hline 18 & EBT19 & 69.90 & $\begin{array}{c}0.00 \\
(0.00)\end{array}$ \\
\hline 19 & EBT20 & 44.80 & $\begin{array}{c}35.90 \\
(36.80)\end{array}$ \\
\hline 20 & EBT21 & 69.90 & $\begin{array}{c}0.00 \\
(0.00)\end{array}$ \\
\hline 21 & EBT22 & 26.10 & $\begin{array}{c}62.66 \\
(52.31)\end{array}$ \\
\hline 22 & EBT23 & 47.66 & $\begin{array}{c}31.80 \\
(34.31)\end{array}$ \\
\hline 23 & EBT24 & 48.20 & $\begin{array}{c}31.04 \\
(33.83)\end{array}$ \\
\hline 24 & EBT25 & 69.90 & $\begin{array}{c}0.00 \\
(\mathbf{0 . 0 0})\end{array}$ \\
\hline 25 & Control & 69.90 & $\begin{array}{c}0.00 \\
(0.00)\end{array}$ \\
\hline $\begin{array}{c}\text { CD @ } \\
5 \%\end{array}$ & & & 2.50 \\
\hline SEm \pm & & & 0.87 \\
\hline $\mathrm{CV}$ & & & 6.30 \\
\hline
\end{tabular}


Table.2 Effect of endophytic bacteria on growth parameters of tomato cv. Arka Vikas

\begin{tabular}{|c|c|c|c|c|}
\hline Treatment & $\begin{array}{c}\text { Germination } \\
(\%)\end{array}$ & $\begin{array}{l}\text { Root length } \\
(\mathrm{cm})\end{array}$ & $\begin{array}{l}\text { Shoot length } \\
(\mathrm{cm})\end{array}$ & $\begin{array}{l}\text { Seedling vigour } \\
\text { index }\end{array}$ \\
\hline T1- EBT3+As & $\begin{array}{c}62.00 \\
(51.92) *\end{array}$ & 8.23 & 6.20 & 728.33 \\
\hline T2- EBT3 & $\begin{array}{c}70.00 \\
(56.77)\end{array}$ & 10.88 & 8.17 & 1352.25 \\
\hline T3- EBT8+As & $\begin{array}{c}64.00 \\
(53.11)\end{array}$ & 9.20 & 8.79 & 1108.26 \\
\hline T4- EBT8 & $\begin{array}{c}74.00 \\
(59.33)\end{array}$ & 14.63 & 12.37 & 2014.77 \\
\hline T5- EBT14+As & $\begin{array}{c}71.67 \\
(57.83)\end{array}$ & 13.70 & 12.02 & 1510.60 \\
\hline T6- EBT14 & $\begin{array}{c}72.00 \\
(58.03)\end{array}$ & 14.50 & 12.56 & 2492.53 \\
\hline T7- EBT18+As & $\begin{array}{c}80.00 \\
(63.42)\end{array}$ & 15.37 & 13.05 & 2402.13 \\
\hline EBT18 & $\begin{array}{c}88.00 \\
(69.74)\end{array}$ & 18.67 & 15.91 & 3302.00 \\
\hline T9- EBT22+As & $\begin{array}{c}67.33 \\
(55.13)\end{array}$ & 11.01 & 8.88 & 1067.39 \\
\hline EBT22 & $\begin{array}{c}74.67 \\
(59.83)\end{array}$ & 12.26 & 10.80 & 1714.73 \\
\hline T11- As & $\begin{array}{c}42.67 \\
(40.76)\end{array}$ & 7.31 & 5.69 & 405.81 \\
\hline $\begin{array}{l}\text { T12- } \\
\text { Control }\end{array}$ & $\begin{array}{c}68.00 \\
(55.53)\end{array}$ & 8.94 & 7.50 & 1073.55 \\
\hline CD & 2.88 & 1.15 & 1.14 & 73.8 \\
\hline SEm \pm & 0.98 & 0.39 & 0.39 & 25.1 \\
\hline CV $(\%)$ & 3.76 & 5.64 & 6.66 & 2.72 \\
\hline
\end{tabular}


Table.3 Effect of endophytic bacteria on per cent disease index (PDI) of tomato early blight caused by Alternaria solani

\begin{tabular}{|c|c|c|c|c|c|}
\hline \multirow[t]{2}{*}{ Treatment } & \multicolumn{5}{|c|}{ Isolates of potential endophytic bacteria } \\
\hline & EBT3 & EBT8 & EBT14 & EBT18 & EBT22 \\
\hline $\mathbf{T}_{1-}$ Seed treatment & $\begin{array}{l}36.27 \\
(37.01)^{*}\end{array}$ & $\begin{array}{l}32.63 \\
(34.82)\end{array}$ & $\begin{array}{l}32.49 \\
(34.73)\end{array}$ & $\begin{array}{l}28.05 \\
(31.96)\end{array}$ & $\begin{array}{l}34.19 \\
(35.76)\end{array}$ \\
\hline $\mathbf{T}_{2}$ - Foliar spray & $\begin{array}{l}38.82 \\
(38.52)\end{array}$ & $\begin{array}{l}34.21 \\
(35.78)\end{array}$ & $\begin{array}{l}30.88 \\
(33.74)\end{array}$ & $\begin{array}{l}26.46 \\
(30.94)\end{array}$ & $\begin{array}{l}31.94 \\
(34.39)\end{array}$ \\
\hline $\mathbf{T}_{3}$ - Soil drench & $\begin{array}{l}36.88 \\
(37.37)\end{array}$ & $\begin{array}{l}33.66 \\
(35.44)\end{array}$ & $\begin{array}{l}28.96 \\
(32.54)\end{array}$ & $\begin{array}{l}24.85 \\
(29.89)\end{array}$ & $\begin{array}{l}34.44 \\
(35.91)\end{array}$ \\
\hline $\mathbf{T}_{4}$ - Seed treatment + foliar spray & $\begin{array}{l}38.24 \\
(38.18)\end{array}$ & $\begin{array}{l}31.35 \\
(34.03)\end{array}$ & $\begin{array}{l}36.74 \\
(37.29)\end{array}$ & $\begin{array}{l}26.30 \\
(30.84)\end{array}$ & $\begin{array}{l}34.38 \\
(35.88)\end{array}$ \\
\hline$T_{5}$ - Seed treatment + soil drench & $\begin{array}{l}33.13 \\
(35.12)\end{array}$ & $\begin{array}{l}36.68 \\
(37.26)\end{array}$ & $\begin{array}{l}32.05 \\
(34.46)\end{array}$ & $\begin{array}{l}20.30 \\
(26.76)\end{array}$ & $\begin{array}{l}36.80 \\
(37.32)\end{array}$ \\
\hline $\mathbf{T}_{6}$ - Foliar spray + soil drench & $\begin{array}{l}34.04 \\
(35.67)\end{array}$ & $\begin{array}{l}34.02 \\
(35.66)\end{array}$ & $\begin{array}{l}28.63 \\
(32.33)\end{array}$ & $\begin{array}{l}26.19 \\
(30.76)\end{array}$ & $\begin{array}{l}30.96 \\
(33.79)\end{array}$ \\
\hline $\begin{array}{l}\mathbf{T}_{7} \text { - Seed treatment }+ \text { foliar spray }+ \\
\text { soil drench }\end{array}$ & $\begin{array}{l}35.49 \\
(36.55)\end{array}$ & $\begin{array}{l}31.94 \\
(34.39)\end{array}$ & $\begin{array}{l}28.49 \\
(32.24)\end{array}$ & $\begin{array}{l}24.58 \\
(29.70)\end{array}$ & $\begin{array}{l}30.12 \\
(33.27)\end{array}$ \\
\hline $\mathbf{T}_{8}-$ Mancozeb & $\begin{array}{l}16.66 \\
(24.06)\end{array}$ & $\begin{array}{l}16.66 \\
(24.06)\end{array}$ & $\begin{array}{l}16.66 \\
(24.06)\end{array}$ & $\begin{array}{l}16.66 \\
(24.06)\end{array}$ & $\begin{array}{l}16.66 \\
(24.06)\end{array}$ \\
\hline $\mathbf{T}_{9}-$ Control & $\begin{array}{l}48.33 \\
(44.02)\end{array}$ & $\begin{array}{l}48.33 \\
(44.02)\end{array}$ & $\begin{array}{l}48.33 \\
(44.02)\end{array}$ & $\begin{array}{l}48.33 \\
(44.02)\end{array}$ & $\begin{array}{l}48.33 \\
(44.02)\end{array}$ \\
\hline
\end{tabular}

Fig.1 Antagonistic activity of different isolates of endophytic bacteria against Alternaria solani

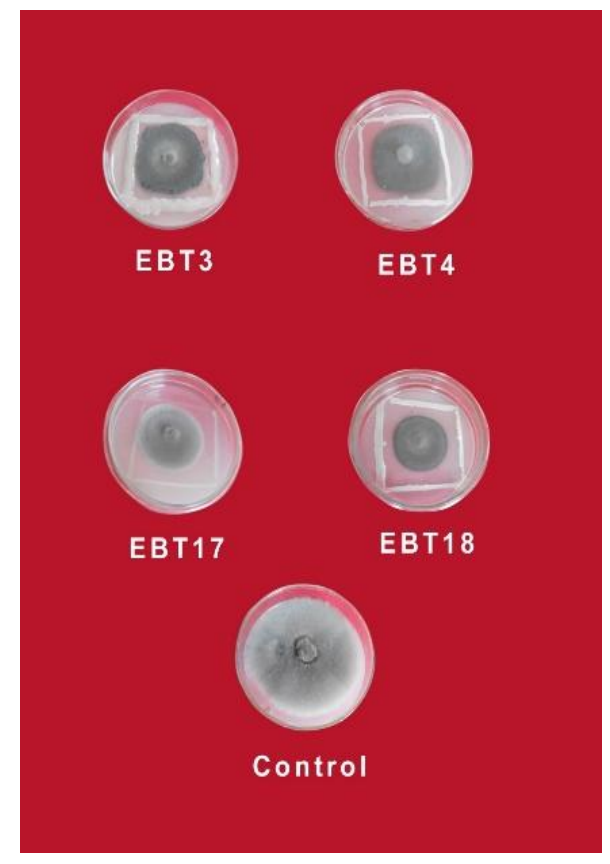


Table.4 Effect of endophytic bacteria on per cent disease control (PDC) of tomato early blight caused by Alternaria solani

\begin{tabular}{|c|c|c|c|c|c|}
\hline \multirow[t]{2}{*}{ Treatment } & \multicolumn{5}{|c|}{ Isolates of potential endophytic bacteria } \\
\hline & EBT3 & EBT8 & EBT14 & EBT18 & EBT22 \\
\hline$T_{1}$ - Seed treatment & $\begin{array}{l}24.88 \\
(29.88)^{*}\end{array}$ & $\begin{array}{l}32.42 \\
(34.68)\end{array}$ & $\begin{array}{l}32.72 \\
(34.85)\end{array}$ & $\begin{array}{l}41.94 \\
(40.34)\end{array}$ & $\begin{array}{l}29.19 \\
(32.66)\end{array}$ \\
\hline $\mathbf{T}_{2}$ - Foliar spray & $\begin{array}{l}19.60 \\
(26.21)\end{array}$ & $\begin{array}{l}29.14 \\
(32.63)\end{array}$ & $\begin{array}{l}36.00 \\
(36.83)\end{array}$ & $\begin{array}{l}45.23 \\
(42.25)\end{array}$ & $\begin{array}{l}33.88 \\
(35.58)\end{array}$ \\
\hline$T_{3}$ - Soil drench & $\begin{array}{l}23.62 \\
(29.03)\end{array}$ & $\begin{array}{l}30.25 \\
(33.31)\end{array}$ & $\begin{array}{l}40.07 \\
(39.25)\end{array}$ & $\begin{array}{l}48.55 \\
(44.15)\end{array}$ & $\begin{array}{l}28.75 \\
(32.41)\end{array}$ \\
\hline $\begin{array}{l}T_{4}-\text { Seed treatment }+ \text { foliar } \\
\text { spray }\end{array}$ & $\begin{array}{l}20.81 \\
(27.09)\end{array}$ & $\begin{array}{l}35.11 \\
(36.32)\end{array}$ & $\begin{array}{l}23.92 \\
(29.25)\end{array}$ & $\begin{array}{l}45.55 \\
(42.43)\end{array}$ & $\begin{array}{l}28.85 \\
(32.47)\end{array}$ \\
\hline $\begin{array}{l}T_{5}-\text { Seed treatment }+ \text { soil } \\
\text { drench }\end{array}$ & $\begin{array}{l}31.39 \\
(34.05)\end{array}$ & $\begin{array}{l}24.07 \\
(29.36)\end{array}$ & $\begin{array}{l}33.68 \\
(35.45)\end{array}$ & $\begin{array}{l}57.94 \\
(49.56)\end{array}$ & $\begin{array}{l}23.76 \\
(29.07)\end{array}$ \\
\hline $\mathbf{T}_{6}-$ Foliar spray + soil drench & $\begin{array}{l}29.55 \\
(32.91)\end{array}$ & $\begin{array}{l}29.60 \\
(32.94)\end{array}$ & $\begin{array}{l}40.73 \\
(39.64)\end{array}$ & $\begin{array}{l}45.79 \\
(42.56)\end{array}$ & $\begin{array}{l}35.87 \\
(36.76)\end{array}$ \\
\hline $\begin{array}{l}\mathbf{T}_{7} \text { - Seed treatment }+ \text { foliar } \\
\text { spray + soil drench }\end{array}$ & $\begin{array}{l}26.48 \\
(30.92)\end{array}$ & $\begin{array}{l}33.95 \\
(35.61)\end{array}$ & $\begin{array}{l}41.03 \\
(39.81)\end{array}$ & $\begin{array}{l}49.13 \\
(44.48)\end{array}$ & $\begin{array}{l}37.62 \\
(37.81)\end{array}$ \\
\hline $\mathbf{T}_{8}-$ Mancozeb & $\begin{array}{l}65.56 \\
(54.05)\end{array}$ & $\begin{array}{l}65.56 \\
(54.05)\end{array}$ & $\begin{array}{l}65.563 \\
(54.05)\end{array}$ & $\begin{array}{l}65.56 \\
(54.05)\end{array}$ & $\begin{array}{l}65.56 \\
(54.05)\end{array}$ \\
\hline $\mathbf{T}_{9}$ - Control & $\begin{array}{l}0.00 \\
(0.00)\end{array}$ & $\begin{array}{l}0.00 \\
(0.00)\end{array}$ & $\begin{array}{l}0.00 \\
(0.00)\end{array}$ & $\begin{array}{l}0.00 \\
(0.00)\end{array}$ & $\begin{array}{l}0.00 \\
(0.00)\end{array}$ \\
\hline Mean & $\begin{array}{l}26.88 \\
(29.35)\end{array}$ & $\begin{array}{l}31.12 \\
(32.10)\end{array}$ & $\begin{array}{l}34.861 \\
(34.35)\end{array}$ & $\begin{array}{l}44.41 \\
(39.98)\end{array}$ & $\begin{array}{l}31.50 \\
(32.31)\end{array}$ \\
\hline Factors & CD & & SE (d) & & \\
\hline Treatments $(\mathbf{T})$ & 1.527 & & 0.771 & & \\
\hline Isolates (I) & 1.138 & & 0.575 & & \\
\hline T X I & 3.414 & & 1.724 & & \\
\hline
\end{tabular}

Fig.2 Effect of potential isolates of endophytic bacteria on per cent disease reduction of early blight caused by Alternaria solani

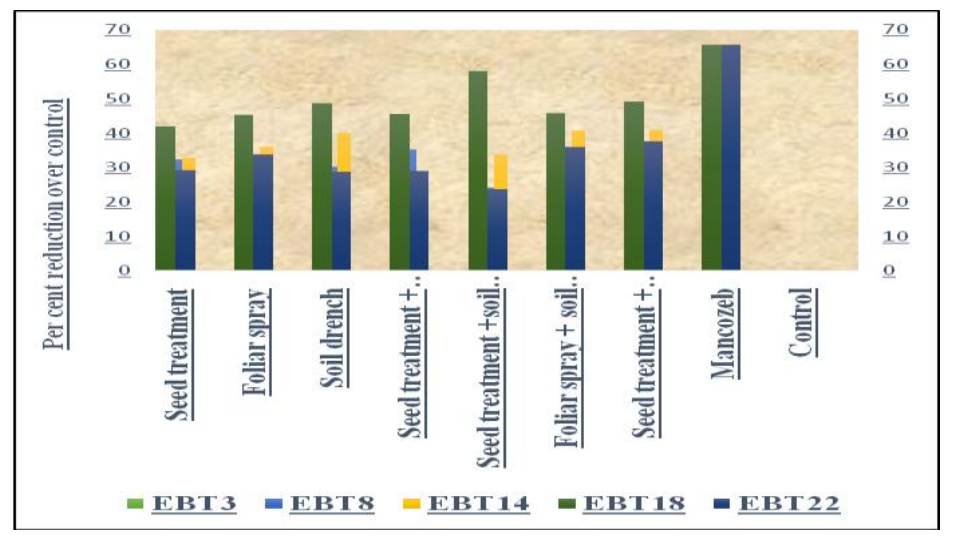


When two application methods were combined, Seed treatment + foliar spray recorded a per cent disease index in the range of 26.30 to 38.24 and the minimum disease index was recorded by the isolate EBT22 and maximum disease index was shown by the isolate EBT3. Seed treatment + soil drench recorded a per cent disease index in the range of 20.30 to 33.13 with the minimum index shown by the isolate EBT22 and maximum by the isolate EBT3. Foliar spray + soil drench recorded a per cent disease index in the range of 26.19 to 34.04 with the minimum disease index by the isolate EBT18 and maximum index by the isolate EBT3.

When seed treatment, foliar spray and soil drench were combined together, it resulted in a disease index in the range of 24.58 to 35.49 with the minimum disease index by the isolate EBT18 and maximum disease index was recorded by the isolate EBT3.

It is evident (Table 3 and 4) that there is significant difference between the isolates EBT3, EBT14 and EBT18 and the isolates EBT8 and EBT22 are on par with each other. The isolate EBT18 was found to be superior among all the isolates followed by the isolate EBT14 evaluated for the management of early blight under the glass house conditions.

The effectiveness of three delivery methods for introducing endophytic bacteria into tomato plants and also the efficacy of delivery methods in reducing bacterial wilt of tomato were studied and the results indicated that the highest suppression resulted from the isolate B2 which gave 71.88 per cent reduction when applied as seed treatment + soil drench (Algam et al., 2005).

The isolate EBT18 has also recorded siderophore production which might be the reason for antagonistic activity of EBT18 against $A$. solani under in vitro (53.84 per cent inhibition) and glass house conditions. When the endophytic bacteria isolated from Solanum elaeagnifolium stem were screened for growth promotion of tomato plants and suppression of Fusarium wilt, the inhibitory effect of B. tequilensis strain SV104 may be due to the siderophore production ability of the strain (Abdallah et al., 2016). Streptomyces strain AzR-051 isolated from Azadirachta indica A. Juss was found to produce higher amounts of IAA and siderophore which might be possible reason for plant growth promotion of tomato seedlings and significant antagonistic activity against $A$. alternata (Verma et al., 2011).

In conclusion this study illustrates the importance of endophytic bacteria in plant growth promotion as well as antifungal activity. All the isolated endophytic bacteria were evaluated for their antagonistic effect against Alternaria solani under in vitro using dual culture technique. Among all the isolates, five isolates (EBT3, EBT8, EBT14, EBT18 and EBT22) were highly effective in inhibiting the mycelial growth of Alternaria solani. The isolate EBT22 recorded maximum inhibition of 62.66 per cent and the isolate EBT8 was better in inhibiting A. solani by 60.99 per cent. Minimum inhibition of 32.04 per cent was recorded by the isolate EBT24. The five potential isolates that were found to be potential antagonists against $A$. solani in dual culture technique were tested for plant growth promotion and reduction of per cent disease index of early blight disease under glass house conditions.

This research concluded that the endophytic bacteria from Lycopersicon esculentum Mill produced one or more characteristics that are different involved in plant growth promotion and showed antagonistic activity against Alternaria solani. Hence, it is proposed that the potential strain observed in the present study can be deployed as bio-inoculant to 
increase tomato growth and to control early blight disease.

\section{References}

Abdul-Baki, A. A and Anderson, J.D. 1973. Vigor determination in soybean seed by multiple criteria. Crop Science. 13: 630633.

Abdallah, R.A.B., Jabnou-khiareddine, H., Mokni-Tlili, S and Daami-Remadi, M. 2016. Biocontrol of Fusarium wilt and growth promotion of tomato plants using endophytic bacteria isolated from Solanum elaeagnifolium stems. Journal of Phytopathology. 164: 811-824.

Algam, S.A., Lin, X.G and Coosemans, J. 2005. Delivery methods for introducing endophytic Bacillus into tomato and their effect on growth promotion and suppression of tomato wilt. Plant Pathology Journal. 4(1): 69-74.

Allu. S, Kumar. N P, Audipudi, A.V. 2014.Isolation, biochemical and PGP characterization of endophytic Pseudomonas aeruginosa isolated from chilli red fruit antagonistic against chilli anthracnose disease. International Journal of Current Microbiology and Applied Sciences. 3(2): 318-329.

Amaresan. N., Jayakumar, V., Krishna Kumar, and Thajuddin, N. 2012. Isolation and characterization of plant growth promoting endophytic bacteria and their effect on tomato (Lycopersicon esculentum) and chilli (Capsicum annum) seedling growth. Annals of microbiology. 62: 805-810.

Backman, P.A and Sikora, R.A. 2008. Endophytes: An emerging tool for biological control. Biological Control. 46(1): 1-3.

Datar, V.V and Mayee, C.D. 1981. Assessment of losses in tomato yield due to early blight. Indian Phytopathology. 34:191-195.
Ghai, S., Sood, S. S., and Jain, R. K. 2007. Antagonistic and antimicrobial activities of some bacterial isolates collected from soil samples. Indian Journal of Microbiology. 47: 77-80.

Hallman. J., Quadt-Hallman, A., Mahafee, W. F Kloepper, J W. 1997. Bacterial endophytes in agricultural crops. Canadian Journal of Microbiology. 43(10): 895-914.

Haddad, N., Krimi, Z and Raio, K. 2013. Endophytic bacteria from weeds promote growth of tomato plants in vitro and in green house. (Eds. In Schneider C, Leifert C, Feldman F.) Endophytes for plant protection: the state of the art. Proceedings of the 5th International Symposium on Plant Protection and Plant Health in Europe, Humboldt University, Germany, 26-29 May, 2013. 27-32.

ISTA. 1993. Proceedings of the International Seed Test Association, International rules for seed testing. Seed Science and Technology. 21:1-152.

Khan, M. S., Gao. J., Zhang, M., Chen, X., Moe, T. S., Du, Y., Yang, F., Xue, J and Zhang, $X$. 2020. Isolation and characterization of plant growth promoting endophytic bacteria Bacillus stratosphericus LW-O3 from Lilium wardii.3 Biotech. 10 (305).

Kobayshi, D.Y., Palumbo, J.D. 2000. Bacterial endophytes and their effects on plants and uses in agriculture. In C.W. Bacon and J.F. White (eds.) Microbial endophytes, Marcel Dekker Inc. New York. 199-233.

Pandey, K.K., Pandey, P.K., Kallo, G and Banerjee, M.K. 2003. Resistance to early blight of tomato with respect to various parameters of disease epidemics. Journal of General Plant Pathology. 69: 364-371.

Rosenblueth, $\mathrm{M}$ and Romero, E. 2006. Bacterial endophytes and their 
interactions with hosts. Molecular Plant-Microbe Interactions. 19 (8): 827 837.

Ryan, R. P., Germaine, K., Franks, A., Ryan, D. J and Dowling, D. N. 2008. Bacterial endophytes: Recent developments and applications. FEMS Microbiology Letters. 278(1): 1-9.

Subramaniam, S and Balabaskar, P. 2012. Consortial effect of endophytic and plant growth promoting rhizobacteria for the management of early blight of tomato incited by Alternaria solani. Plant Pathology \& Microbiology. 3:7.

Verma, V.C., Singh, S.K and Prakash, S. 2011. Bio-control and plant growth promotion potential of siderophore producing endophytic Streptomyces from Azadirachta indica A. Juss. Journal of Basic Microbiology. 51: 550556.

Vincent, J.M. 1947. Distortion of fungal hyphae in the presence of certain inhibitors. Nature. 159: 850.

\section{How to cite this article:}

Sai Sushma, B., B. Vidya Sagar, S. Triveni and Uma Devi, G. 2020. Effect of Endophytic Bacteria on Tomato Plant Growth Promotion and Tomato Early Blight Management. Int.J.Curr.Microbiol.App.Sci. 9(11): 2362-2374. doi: https://doi.org/10.20546/ijcmas.2020.911.283 